DOI: $10.2478 / \mathrm{v} 10025-011-0003-7$

\title{
Controlling of eutrophication in aquatic environments
}

\author{
Marek Jerzy GROMIEC ${ }^{1)}$, Tomasz Marek GROMIEC ${ }^{2)}$ \\ 1) Warsaw University of Ecology and Management \\ ${ }^{2)}$ European Environmental Center-Krevox
}

\begin{abstract}
This paper reviews various methods of eutrophication controlling in water bodies. The purpose of this presentation is to analyze the role of eutrophication in water bodies and to address the importance of various instruments of controlling this process.
\end{abstract}

Key words: aquatic environments, eutrophication, nitrogen and phosphorus removal, nutrients, treatment technologies, watershed models

\section{INTRODUCTION}

Introduction of excess nutrients, as well as other pollutants, into water bodies are causing many changes in aquatic environments, since they accelerate the process of eutrophication. The term "eutrophication", usually refers to the natural or artificial addition of nutrients to water bodies and to the effects of these added nutrients. It is possible that either nitrogen or phosphorus will be the limiting nutrient controlling the process of eutrophication in a water body. It is recognized that phosphorus is typically the limiting nutrient in freshwater, whereas nitrogen is typically limiting in estuarine or marine waters. However, the relationships are more complex than this. Environmental conditions in most water bodies are dominated by many factors, including seasonal changes and interactions with bottom sediment. The dynamics of limiting nutrients are not well known in most water bodies. Currently, the best nutrient management policy is based on simultaneous reduction of both nitrogen and phosphorus inputs to water bodies.

\section{CAUSES AND EFFECTS OF EUTROPHICATION}

The causes of eutrophication are related to meteorological and climatic status, anthropogenic causes and features and characteristics of water bodies. The anthropogenically induced nutrient loads represent the main problem and include the in- 
direct loads which originate from atmospheric deposition or rivers and wastewaters including that from agriculture which represent the main point sources. Non-point source nutrient loads resulting from agricultural practices represent the main diffiuse sources. A fourth cause is an internal nutrient load, which is related to release from sediments during hypoxic and anoxic conditions. Increased concentrations of nitrogen and phosphorus are the main primary causes of eutrophication. However, substances other than inorganic phosphorus and nitrogen compounds can also contribute to eutrophication. It should be stressed that the whole population is contributing to the problem of eutrophication by our life style.

The complex relation between natural and anthropogenic processes in relation to nutrient dynamics makes it difficult to understand cause and effect relationships. Therefore, only some examples of eutrophication are presented below. The primary effects of eutrophication are related to biological, chemical and physical disturbances. The increasing production of algae biomass, the decreasing amount of silica, and the increasing turbidity of the water, are well known examples. Cyanobacterial blooms may cause damage to organisms and result in odour problems. Sedimentation associated with primary production and occurrence of hypoxia and anoxia are well known examples of secondary and tertiary effects caused by eutrophication (LUNDBERG, 2005).

\section{WATER BASIN POLICY AND NUTRIENT MANAGEMENT}

It is well recognised that river basin management is the key for sustainability in water and land use management. In the European Union (EU), a Water Framework Directive (WFD) is the most significant legislative instrument of policy in the water management field .This legal instrument provides a framework for each member state to develop a common basis for the sustainable use of water and for the protection of water. The main requirement of the WFD is that EU member states ensure that all waters are in good status by the end of 2015 .

The most important features of WFD are that it aims to manage the water environment as a whole on a river basin basis. In addition, it calls to use a combined approach to pollution control, setting limit values to control emissions from individual point sources, and establishing water quality standards to limit the cumulative impact of emissions and diffuse sources of pollution.

Therefore, in nutrient management it is necessary to assess the impact of human activities on water bodies in each river basin, taking into consideration nutrient inputs from point sources and from diffuse sources and other human activities that may impact water status. Furthermore, it is necessary to establish and implement a legally binding program of measures. This program to achieve the defined quality objectives will have to follow the above mentioned combined approach, using the setting of emission limit values and water quality standards. 


\section{WATER QUALITY CRITERIA FOR NUTRIENT MANAGEMENT}

Population growth in cities bas resulted in an effort to reduce nutrient loads in municipal wastewaters on receiving water bodies. A number of options exist for removal of nitrogen and phosphorus from wastewaters. The strategies to achieve low concentrations of nitrogen and phosphorus are usually based on water quality criteria and effluent standards (BARNARD and STEICHEN, 2006).

In 2001, the United States Environmental Protection Agency published water quality criteria with stringent nitrogen and phosphorus requirements. Depending on the eco-region, the water quality criteria are as follows:

- total nitrogen (TN) - from 0.12 to $2.18 \mathrm{mg} \mathrm{TN} \cdot \mathrm{dm}^{-3}$,

- total phosphorus (TP) - from 10 to $76 \mathrm{mg} \mathrm{TN} \cdot \mathrm{dm}^{-3}$.

These water quality criteria for 17 eco-regions of the USA are currently being evaluated.

\section{EFFLUENT STANDARDS FOR NUTRIENT CONTROL}

There are also stringent requirements for low levels of effluent nutrient concentrations in many regions of the world. In Europe, according to the EU urban wastewater treatment directive $(91 / 271 / \mathrm{EC})$ the effluents also have to meet guidelines on the content of phosphorus and nitrogen. However, when a territory is designed as a sensitive area, more advanced nutrient removal should be provided according to article 5.4 of the directive. These standards for nutrients concentrations are related to population equivalent (P.E.), where P.E. is equal to $60 \mathrm{~g} \mathrm{BOD}_{5} \cdot \mathrm{d}^{-1}$.

In Poland, a decree of the Minister of Environment, concerning the conditions which must be met by wastewaters discharged to waters, was issued in 2006. Standards for urban wastewater treatment in Poland are the same as in the directive 21/271/EC.These standards for total nitrogen and total phosphorus are as follows:

- for agglomerations from 15000 to 100000 P.E.:

- total nitrogen (TN) - $15 \mathrm{mg} \mathrm{TN} \cdot \mathrm{dm}^{-3}$ or $80 \%$ reduction,

- total phosphorus (TP) $-1.0 \mathrm{mg} \mathrm{TP} \cdot \mathrm{dm}^{-3}$ or $85 \%$ reduction,

- for agglomerations above 100000 P.E.:

- total nitrogen $(\mathrm{TN})-10 \mathrm{mg} \mathrm{TN} \cdot \mathrm{dm}^{-3}$ or $85 \%$ reduction,

- total phosphorus (TP) $-1.0 \mathrm{mg} \mathrm{TP} \cdot \mathrm{dm}^{-3}$ or $90 \%$ reduction.

Standards for total nitrogen and total phosphorus are not specified for agglomerations from 2000 to 15000 P.E. However, there is presently a great emphasis on reaching very low levels of effluent phosphorus. For example, in Germany (Berlin area), limiting phosphorus removal to $0.05 \mathrm{mg} \mathrm{TP} \cdot \mathrm{dm}^{-3}$ is required for the larger plants to further reduce eutrofication of the local surface water bodies. 


\section{WASTEWATER TREATMENT TECHNOLOGIES}

The theoretical and practical aspects of biological nitrogen removal are well understood.Nitrification, as the first step of nitrogen removal, is conversion of ammonia to nitrate. The first step is followed by denitrification, as the second step. Denitrification is a conversion of nitrate to nitrogen gas.

A large number of processes have been developed and applied to achieve combined nitrification-denitrification. Also, chemical precipitation of phosphorus is the most common application in wastewater treatment. However, the biological phosphorus removal plants have been used in many wastewater treatment plants.

Now, combined biological nutrients removal systems are capable of removing phosphorus and nitrogen, as well as dissolved biodegradable organics and suspended solids. A large number of processes have been developed and applied to achieve combined nutrients removal, such as: Bardenpho process, $\mathrm{A}^{2} \mathrm{O}$ process, UTC process, VIP process, sequencing batch reactor (SBR), PhoStrip process, Orbal process and others .

The above criteria and requirements require technologies to obtaining very low dissolved organic nitrogen concentrations in the treated effluents. Since the residual effluent dissolved organic nitrogen (DON) is composed of non-biodegraded nitrogen forms, a method is needed to assess the biodegrability of effluent DON (PAGILlA et al., 2006).

\section{WATERSHED MODELS}

Watershed models have made significant contributions to various aspects of water resources, including eutrophication. The development of watershed models has been mainly influenced by two technological advancements, such as the computer technology and geoiformation technology. The geoinformation systems are mainly consisted of Geographic Information System (GIS) and remote sensing. These advancements have made possible to analyse influence of point and nonpoint sources on water quality of water bodies (GROMIEC, 2007).

Over the past few decades, a large number of water quality models have been developed. Renowned examples include the following: STREAM, QUALE, CEQUAL-W2, HAR03, WASP/EURO, MIKE BASIN, SHE, AGNEPS, ANSWERS, BASINS and many others. The integration of water quality models with a GIS has been beneficial for the simulation of eutrophication, particularly from non-point sources. For example, a set of models such as DAISY GIS, MIKE BASIN, MIKE 11 was applied for the Parsenta basin (GROMIEC and JENSEN, 2005). 


\section{PROGRESS IN NUTRIENTS REMOVAL IN POLAND}

Poland has decided to apply the option of article 5.4 of the directive 91/271/EC. The percentage of reduction in overall loads entering all the country s treatment plants has therefore to be at least $75 \%$ removal for phosphorus and at least $75 \%$ for nitrogen. Therefore, a number of wastewater treatment plants with increased nutrients removal for cities and villages has increased from 426 in the year 2000 to 808 in 2008 (GUS, 2009).

The amount of treated wastewaters with increased nutrient removal is different in various river basins. In 2008, these amounts of treated wastewaters with increased nutrient removal were as follows:

- Vistula River basin - $484.3 \mathrm{hm}^{3}$,

- Narew from the source up to the Biebrza estuary $-16.7 \mathrm{hm}^{3}$,

- Narew from the Biebrza up to the Bug estuary $-12.7 \mathrm{hm}^{3}$,

- Bug River basin - $23.1 \mathrm{hm}^{3}$,

- Narew from the Bug estuary to the Vistula estuary $-12.2 \mathrm{hm}^{3}$.

Various measures of nutrients control have contributed to lower nutrient loads from Poland to the Baltic Sea. In 1995, the total nitrogen load was $214718 \mathrm{t} \cdot$ year $^{-1}$ and the total phosphorus load was $14209 \mathrm{t}^{\mathrm{t}} \mathrm{year}{ }^{-1}$, while in 2005 these amounts were $146303 \mathrm{t} \cdot$ year $^{-1}$ and $8910.7 \mathrm{t} \cdot \mathrm{year}^{-1}$, respectively.

\section{RESEARCH NEEDS}

Long-term interdisciplinary studies should be established to improve our understanding of eutrophication as well as to formulate management procedures. These solutions of eutrophication problem should be both preventive and corrective.

The role of various sources of nutrients, including the point and non-point sources, should be investigated in various river basins. The mathematical water quality/watershed models should be used to predict the consequences of eutrophication in water bodies and the effect of various corrective measures. A system for efficient measuring and monitoring of eutrophication, that could be practically used in diffrent water bodies, should be developed.

Various methods for efficient removal of nutrients from point sources should be investigated and compared from the performance and costs point of view. Agricultural management practices should be developed to effectively control non-point sources of nutrients. 


\section{CONCLUSIONS}

Anthropogenic activities contributing to organic pollution and nutrients have led to large scale eutrophication problems in many water bodies. Therefore, eutrophication management should be based on controlling both point and non-point sources in a given watershed. Management of nutrients is only possible if all sources of the nutrients and their fate in the catchment are known.

As far as the nutrient point sources are concerned, there is presently emphasis on reaching very low levels of effluent nitrogen and phosphorus concentrations. Hawever, successful strategies for nutrient management need to be based also on economic considerations. Especially, the cost of removing the remaining soluble organic nitrogen from wastewaters must be justified by the environmental impact. Therefore, cost-effectiveness and sustainability of the existing technologies for nutrient removal should be evaluated. Also, developing cost-effective nutrient control technologies is one of the major challenges in the years to come.

In successful strategies for nutrient management it is also necessary to address non-point sources, particularly from agriculture. The optimal applications of scientific knowledge for nutrient management can be achieved by the use of modelling tools. Further research in this area is required for the better prediction of the ecological risks of eutrophication.

\section{REFERENCES}

1. Bernard J.L., Steichen M.T., 2006. Where is biological nutrient removal going now? Water Science and Technology, 53, 3: 155-164.

2. Główny Urząd Statystyczny: Środowisko (Environment), 2009. Warszawa, GUS.

3. GROMIEC M.J., 2007. Management of eutrophication. In: Fish physiology, toxicology, and water quality. US Environmental Protection Agency. Office of Research and Development. EPA/600/ r-07/010. Washington, D.C., February 2007.

4. GROMIEC M.J., JeNSEN J.K. (Eds), 2005. Controlling non-point pollution in Polish catchments. Water Quality Protection Libery IWA PLC, 19. Copenhagen/Warsaw.

5. LundBerg C., 2005. Conceptualizing the Baltic Sea Ecosystem - An interdisciplinary tool for environmental decision making. Ambio 34, 6: 433-439.

6. Pagilla K.R., Urgun-Demitras M., RamaniI R., 2006. Low effluent nutrient technologies for wastewater treatment. Water Science and Technology, 55, 3: 165-172. 


\section{STRESZCZENIE}

\section{Kontrola eutrofizacji w środowiskach wodnych}

Słowa kluczowe: eutrofizacja, modele zlewniowe, substancje biogenne, środowiska wodne, technologie oczyszczania, usuwanie azotu i fosforu

W pracy zdefiniowano przyczyny i skutki eutrofizacji. Na tym tle przedstawiono rolę zlewniowej polityki wodnej, związanej z odprowadzaniem substancji biogennych do wód. Podano zarówno kryteria jakości wody, jak również standardy oczyszczania ścieków w aspekcie redukcji azotu i fosforu. O ile standardy oczyszczania ścieków w Unii Europejskiej dotyczące substancji biogennych zostały dość dobrze ustanowione, to kryteria jakości wody powinny zostać dopracowane wzorem kryteriów ,zaproponowanych w Stanach Zjednoczonych Ameryki Północnej.

Zaprezentowano nowoczesne technologie oczyszczania ścieków, które umożliwiają usuwanie azotu i fosforu. Istnieje możliwość dalszego zwiększenia możliwości redukcji substancji biogennych, zarówno za pomocą istniejących technologii, jak też opracowania całkowicie nowych technologii. Wymusić to może konieczne zaostrzenie standardów oczyszczania ścieków w pewnych przypadkach. Przedstawiono również modele zlewniowe, umożliwiające planowanie systemów redukcji substancji biogennych i podjęcie działań ochronnych.

Przedstawiono również postępy w usuwaniu substancji w Polsce, w tym w zlewniach Narwi i Bugu. Istnieje potrzeba dokonania szczegółowej analizy stanu realizacji oczyszczani ścieków z podwyższonym stopniem usuwania substancji biogennych w ramach Krajowego Programu Oczyszczania Ścieków Komunalnych. Problemem do rozwiązania pozostanie sprawa zmniejszenia ładunków substancji biogennych odprowadzanych ze spływami powierzchniowymi, szczególnie z obszarów rolniczych. Zaproponowano kierunki dalszych badań nad kontrolą eutrofizacji systemów wodnych.

Reviewers:

Prof. Waldemar Mioduszewski

Dr Marek Ślesicki 